\title{
Returning Merchandise: Registering a Consumer Complaint ${ }^{1}$
}

Mary N. Harrison ${ }^{2}$

\section{Overview}

"Satisfaction guaranteed or your money cheerfully refunded." Many consumers view this policy as an unwritten law that governs all sales transactions between a retailer and a consumer. Many retailers are exceedingly generous in their return policies. Others either cannot afford this policy or do not desire to follow it.

Returning merchandise for whatever reason can generate additional retailing costs which must be absorbed by the merchant. However, accepting returned merchandise creates good customer relations, encouraging additional sales and customer confidence.

Consumers return purchases for a variety of reasons. Sometimes they change their minds and do not want an item. Perhaps the purchase cant be used as planned, the color or fit is wrong or the product is defective. Many times there would be no need to return items if the customer shopped carefully and planned ahead. However, even the most efficient shopper will occasionally find it necessary to return a purchase for exchange or replacement.

\section{Do merchants have to accept returned merchandise?}

Florida law requires retail stores that do not accept returned merchandise to post a sign informing the potential customer of this policy. The sign must be located at the point of sale, for example, near the cash register or checkout location.

Under this law the absence of a sign means a return policy does exist. If there is no sign, the store must accept merchandise returned within 7 days from the date of purchase - provided it is unused and in the original carton, if one was furnished. The store can require proof of purchase such as a sales receipt. The store also determines whether the returned item will be accepted for exchange only or for a cash refund. The stores return policy must be given to any consumer requesting it. Any store that wishes to offer a more generous return policy may do so. This law does not apply to the sale of food, perishable goods, custom-made items, things that have been altered at the customer's request, or merchandise that cant be resold because of any law or regulation. (This law applies to merchants in Florida and sales made in Florida.)

1. This document is Fact Sheet 5011, one of a series of the Department of Family, Youth and Community Sciences, Florida Cooperative Extension Service, Institute of Food and Agricultural Sciences, University of Florida. Revised: June 2005. Original publication date: January 1994. Visit the EDIS Web Site at http://edis.ifas.ufl.edu.

2. Mary N. Harrison, Professor; and reviewed by Josephine Turner, professor, both of the Department of Family, Youth and Community Sciences, Cooperative Extension Service, Institute of Food and Agricultural Sciences, University of Florida, Gainesville, Florida 32611.

The Institute of Food and Agricultural Sciences (IFAS) is an Equal Opportunity Institution authorized to provide research, educational information and other services only to individuals and institutions that function with non-discrimination with respect to race, creed, color, religion, age, disability, sex, sexual orientation, marital status, national origin, political opinions or affiliations. U.S. Department of Agriculture, Cooperative Extension Service, University of Florida, IFAS, Florida A. \& M. University Cooperative Extension Program, and Boards of County Commissioners Cooperating. Larry Arrington, Dean 
Before buying, make sure you clearly understand the details of a stores policy regarding returns.

- Will the store accept returns? if so will a cash refund be given?, or must you select other merchandise?

- How long do you have to return the purchase?

- What proof of purchase is required? (Keep each sales receipt until you are certain you do not want to exchange the item, it is not defective, and its warranty has expired.)

\section{What if there is a problem with a purchase?}

Remember the merchant expects to resell returned merchandise. Make sure it is unused and correctly repackaged with all enclosures. It should look like it did when you bought it. Many stores have a customer relations department that accepts returns. If not, ask the sales associate where to return the purchase. Be courteous and try to choose a time when the store is not busy. Return the purchase immediately, no store wants returned Christmas merchandise in June.

Most misunderstandings revolve around the customers failure to understand the stores policies. Remember, stores that accept returns determine their own return policies. Most will not give a cash refund without a sales receipt, but will exchange the merchandise. If the merchandise has gone on sale many retailers will credit the sale price only. If the purchase was charged to a credit card, the card is refunded. Most complaints are easily resolved with a stores supervisor. If not, violations can be reported to the Florida Department of Agriculture and Consumer Services, 1-800-HELP-FLA.

\section{What if a purchase is ordered via the Internet, mail order, telephone, or TV?}

Florida law applies only to retailers located in and selling in Florida. There are Federal regulations that relate to the delivery of purchases from US retailers but not foreign markets. When ordering merchandise from distant locations it is very important to check the reliability of the seller and the return policies.

\section{To whom should an ordered, purchased product be returned?}

The safest way to pay for ordered merchandise is to use a credit card for payment. It offers the greatest protection in case the item is lost, not received, or has to be returned. For returns, refer to the advertisement or instructions that came with the merchandise. Be sure to return the item to the mailing address specified and insure it. (Keep your insurance receipt until you are sure the item has been received.) Some mail order companies require that before a purchase is returned you contact them for instructions or to request permission to return the purchase. In your communication clearly state what you want, a refund or a replacement. If you call be sure to write down the name of the person you talked with and the time and date. Follow up with a letter containing this information. Restate what was promised.

\section{What if a new purchase is defective?}

If a new product has a defect it should be returned to the place of purchase immediately regardless of the stores return policy. Defective purchases are covered by the Federal Magnuson Moss Warranty Act. New, unused products have an implied warranty regarding their fitness for purpose and use. When you return a defective product in its original package and condition the merchant must refund the purchase price or replace the item unless it was sold "as is."

\section{What if a purchase breaks or becomes defective after a short period of use?}

Most consumer disputes arise over products that become defective when used. If the defect becomes evident immediately following the first periods of use, the item should be returned to the retailer. Most will either replace the item or issue a refund.

Sometimes products give service for a short period of 
time and then fail. This may cause uncertainty about what to do and who is responsible. Such problems are usually considered warranty problems. Some merchants warranty products they sell for a short period of time, example 30 days, after which time the manufacturers warranty applies. Many items do not have a written manufacturers warranty.

\section{What steps should be taken to resolve a problem?}

As a consumer you have the right to expect quality products and services at fair prices. The following steps may help you resolve any problems or misunderstandings that arise.

- Identify the problem. What is wrong with the item or purchase? Is it poor quality or defective? Did the person you contacted ignore your request, refuse to handle your complaint or have no authority to do so? First, contact the store or retailer that sold you the item or performed the service. Go to the customer service department or person authorized to accept returns. Calmly and accurately explain the problem. If possible, carry the item with you to show the defect or problem. If that person is not helpful, ask for the supervisor or manager and restate your case. (Most problems are resolved at this level, but if not, go to the next.)

- Records are essential for resolving consumer problems. At the first indication of a problem keep accurate records. Include such information as date of purchase, serial number and name of item, what the problem is and when it occurred, who you contacted, when and what was said. Save copies of letters that you write and those you receive.

- If talking to store personnel or company representatives does not resolve the problem, you will need to put your request in writing. This will help document your efforts. Your letter should be addressed to the manager or owner of the business and should include:

- Your name, address, home and work telephone number (if any), and account number (if appropriate).
- A brief, clear description of the problem and your efforts to resolve it. Include dates and names of your contact. Clearly state what you want done and when (be reasonable).

- Copies of all documents relating to the problem. Send copies, not originals.

- Don't write an angry, sarcastic or threatening letter. This will cause the reader to be defensive and will hurt your case. If possible, type your letter. If it is handwritten, be sure it is easy to read. Keep a copy of your letter.

- If the problem is not resolved, don't give up. Write the manufacturer. Use the same format for this letter and send a copy to the store. If that does not settle it, contact the appropriate regulatory authorities.

If you do not have the name and address of the manufacturer, try looking on the Internet or contacting your local library for help.

Most companies will acknowledge a complaint letter within two or three weeks. If you do not hear from the company, send a second letter. On the bottom of the second letter show that you are sending copies of the letter to the Better Business Bureau in the company's area and to the appropriate regulatory authority. If there is still no reply, contact the appropriate regulatory authority and register your complaint by providing a clearly written statement of the problem and your efforts to resolve it. Be sure to include copies of your letters and any supporting documents.

Resolving a consumer complaint sometimes requires persistence and patience. It also requires accurate records. Identification of problem areas is one way in which consumers contribute toward the goal of better products and services. Most retailers and manufacturers agree consumer complaints keep them on their toes and can lead to increased sales by developing confidence and customer loyalty. 